\title{
Marginalisasi Pekerja Perempuan Sektor Informal Dalam Perspektif Hukum (Studi Kasus di Desa Teluk Wetan, Kecamatan Welahan, Kabupaten Jepara)
}

\author{
Tri Widya Kurniasari ${ }^{1}$ \\ Dosen Fakultas Hukum Universitas Malikussaleh
}

\begin{abstract}
Emancipation is a condition where someone getting freedom or chance to play a role in all aspects of life. It is the same thing that should be experienced by women. In fact, in an era which has given the same chances between men and women in their rights, many women have not experienced the equal chances yet. It is not only caused by the limited supporting facilities, but also come from the culture and view of life of the community itself. Women are still considered as the second citizens in a community and that they should be just staying at home. Marginalization towards women workers is not only limited on the income, but also on chances to be the owners of their own business. This condition, ironically, is often times supported by the women themselves as well. Even the religion doctrine has often been used as the main reason. This is the same thing happen in village of Teluk Wetan, Jepara District. The women there working for rattan industry still receive unequal treatment, both from income aspect and from chance aspect in the access to science and technology. If we compare between women and men in relation to production process in informal sector, the women in fact give more adding value than men. Beside the two factors above, actually, government attention also has a big enough role in the distribution of chances for women. The final result of a production process getting attention from the government as the authority will be very different with the one which is run without getting involved by the government specifically for the firm from the informal sector. However, the most important thing of all is thet efforts to minimize marginalization among women workers as vulnerable groups must be done because it has been proved that the marginalization generates a big obstacle for women to make equality with men in any aspects.
\end{abstract}

Keywords:

Informal sectors female workers, marginalization, legal perspective 


\section{PENDAHULUAN}

Pembangunan ekonomi merupakan salah satu pilar penyangga kelangsungan hidup suatu bangsa. Demikian pula yang terjadi di Indonesia. Berkali-kali bangsa ini diuji oleh berbagai masalah ekonomi yang seringkali menjadi kendala bagi pembangunanya. Dari berbagai masalah ekonomi yang telah menimpa bangsa ini ternyata usaha di sektor informal telah membuktikan kemampuannya untuk tetap bertahan dalam menghadapi kendala di berbagai situasi dan kondisi.

Berada di luar sistem (karena tidak memiliki izin usaha sebagai dasar hukum dalam berbagai hal terkait proses produksi) mengakibatkan usaha di sektor informal bersifat luwes dan dinamis. Artinya, usaha di sektor informal tidak terikat aturan yang menjadi standar baku operasional sebuah usaha. Mereka memiliki waktu dan jenis usaha yang fleksibel mengikuti perkembangan jaman. Begitu pula dengan hubungan hukum yang terbentuk antara majikan sebagai pemberi kerja dengan pekerjanya. Sama dengan sistem managemen usaha yang dilakukan berdasarkan rasa kekeluargaan, maka hubungan hukum itupun terbentuk berdasarkan azas kekeluargaan. Umumnya antara majikan dan pekerja memiliki hubungan keluarga, kerabat, teman atau tetangga. Kalaupun tidak memiliki hubungan tersebut umumnya pekerja tersebut direkomendasikan oleh orang yang memiliki afiliasi dengan si majikan/pemilik usaha.

Hubungan hukum yang terbentuk menjadi dasar sistem pengupahan dalam usaha sektor informal. Di sektor ini dikenal adanya sistem upah borongan atau per piece work, upah tetap dan semi tetap serta sistem subkontrak. Masing-masing sistem pengupahan ini ditentukan pada jenis pekerjaannya. Perbedaan jenis pekerjaan ini membedakan pula upah para pekerjanya. Antara pekerja yang satu dengan pekerja yang lain bisa terjadi perbedaan jumlah upah yang sangat mencolok yang seringkali menimbulkan gap penghasilan. Hal ini tidak terlalu menjadi masalah bila disadari antar jenis pekerjaan yang satu dengan jenis pekerjaan yang lain memiliki tingkat kesulitan yang berbeda. Namun akan menjadi sebuah masalah bila dengan beban kerja yang sama para pekerja menerima upah 
yang berbeda. Kondisi ini umumnya terjadi antara pekerja perempuan dan pekerja laki-laki. Dengan prediksi bahwa tenaga laki-laki lebih menjanjikan hasil produksi yang lebih banyak dibanding perempuan yang selalu dikonotasikan sebagai "mahluk lemah" maka diskriminasi terhadap pekerja perempuan pun dilegalkan dan menjadi sesuatu yang wajar terjadi di lingkungan usaha, terutama di sektor informal. Terlebih lagi tingkat pendidikan pekerja laki-laki yang umumnya lebih tinggi dibanding pekerja perempuan mengakibatkan diskriminasi ini dilanggengkan. Bahkan seringkali mengakibatkan terjadinya marginalisasi bila telah sampai pada tahap akses peningkatan di lingkungan usahanya.

Seperti yang terjadi di Desa Teluk Wetan di Kabupaten Jepara. Wilayah ini terkenal sebagai sentra industri rotan. Ada dua jenis hasil produksi yang dihasilkan di sentra ini, yaitu mebel/furniture rotan dan handycraft. Pekerja laki-laki memonopoli jenis produksi mebel rotan dan pekerja perempuan memonopoli jenis produksi handycraft. Hal ini terkait dengan tingkat kesulitan dan ketelitian dalam proses produksinya.
Pada jenis produksi mebel lebih banyak dibutuhkan tenaga yang cukup kuat untuk membuat kerangka/frame mebel dari kayu jati dan menganyam/mengikat rotan pada kerangkanya. Belum lagi untuk finishing, yaitu mengamplas dan mengecat sesuai warna yang diinginkan konsumen. Tahap ini seringkali menyita waktu dan membutuhkan stamina yang cukup kuat sehingga pekerja laki-laki lebih memenuhi standar produksi dibanding pekerja perempuan. Sementara pada produksi handycraft, ketelitian lebih dibutuhkan sebab jenis pekerjaan ini sangat detil sehingga membutuhkan kesabaran dan ketekunan yang umumnya dimiliki oleh pekerja perempuan.

Dalam jenis produksi handycraft pekerja laki-laki juga memiliki beban kerja yang secara khusus diperuntukkan baginya, yaitu untuk melakukan pengelasan (bila dibutuhkan frame dari besi) atau pembentukan kerangka dari kayu jati seperti pada jenis produksi mebel. Pekerja laki-laki juga bisa mengerjakan jenis pekerjaan yang umumnya dikerjakan oleh pekerja perempuan sehingga terjadi perbedaan upah untuk jenis 
pekerjaan yang sama karena umumnya para pekerja laki-laki diupah tetap per harinya sedang pekerja perempuan diupah per piece work. Disinilah kemudian timbul masalah yang tanpa disadari sebenarnya mengarah pada suatu bentuk marginalisasi.

Awalnya merupakan diskriminasi dalam sistem pengupahan dimana untuk jenis pekerjaan yang sama antara pekerja laki-laki dan perempuan dapat menerima upah yang berbeda. Namun lama kelamaan dengan sikap yang "nrimo" itu maka pekerja perempuan termarginalkan terhadap upah dan akses fasilitas kerja, sebab dengan tingkat pendidikan yang rendah pekerja perempuan dianggap kurang layak untuk mendapatkan upah yang lebih tinggi atau mendapatkan kesempatan dari perusahaan untuk meningkatkan ketrampilannya.

Studi ini secara khusus membahas marginalisasi terhadap hak ekonomi pekerja perempuan di Desa Teluk Wetan tersebut di mata hukum dan solusi yang dapat meminimalkan marginalisasi tersebut dengan mengangkat judul Marginalisasi Pekerja Perempuan
Sektor Informal Dalam Perspektif Hukum (Studi Kasus di Desa Teluk Wetan, Kecamatan Welahan, Kabupaten Jepara).

\section{METODE PENELITIAN}

Jenis penelitian ini merupakan penelitian kualitatif, yang dipakai sebagai prosedur penelitian yang menghasilkan data deskriptif mengenai permasalahan terkait dengan marginalisasi terhadap hak ekonomi pekerja perempuan di Desa Teluk Wetan tersebut di mata hukum dan solusi yang dapat meminimalkan marginalisasi tersebut yang diuraikan dari pengamatan atas kata-kata tertulis dalam bentuk dokumen maupun dari lisan orang-orang atau perilaku yang dilakukan oleh orangorang, dalam hal ini Pihak Pekerja Perempuan dan Pihak Majikan sebagai pemberi kerja. Dalam jenis penelitian kualitatif ini proses analisa data dilakukan dengan melakukan verifikasi data yang diperoleh dari ketiga tahapan penelitian, yaitu studi pustaka, wawancara dan Focus Group Discussion.

Hasil temuan dari studi pustaka diverifikasi dengan hasil temuan dua tahap penelitian lainnya, dan analisa kemudian diarahkan 
untuk melihat kesenjangan antara data-data yang ada.

Pendekatan penelitian yang digunakan adalah gabungan antara pendekatan penelitian hukum normatif (legal research) dengan pendekatan antropologi hukum. Pendekatan penelitian hukum normatif dilakukan untuk menemukan seberapa jauh kepentingan dan hak pekerja sektor informal, khususnya yang termasuk dalam industri kecil, telah diakomodir didalam hukum ketenagakerjaan di Indonesia yang berlaku saat ini.

$$
\text { Sedangkan pendekatan }
$$

antropologi hukum dilakukan untuk memahami permasalahanpermasalahan, termasuk kerentanankerentanan sekaligus peluang-peluang yang dihadapi pekerja sektor informal dalam konteks perekonomian nasional dan global. Selain itu, melalui pendekatan antropologis diharapkan dapat dirumuskan strategi penanggulangan risiko sekaligus pemanfaatan peluang bagi pekerja informal, dengan memberi perhatian khusus untuk melindungi kelompok yang paling rentan dieksploitasi (the most vulnerable groups). Penelitian ini sendiri bersifat deskriptif analisis yaitu penelitian yang menghasilkan data yang deskriptif analisis dengan metode yang dipakai untuk menggambarkan suatu kondisi dan keadaan yang berlangsung supaya objek penelitiannya berdasarkan teori hukum atau peraturan perundangundangan yang berlaku.(Amiruddin, 2012) Dalam hal ini untuk menjelaskan tentang situasi riil perlindungan hukum bagi para pekerja sektor informal.

\section{PEMBAHASAN}

Berdasarkan hasil penelitian bahwa di dalam perjanjian pengangkutan barang melalui perusahaan angkutan khususnya di darat, sebagaimana di dalam perjanjian pada umumnya para pihak mempunyai hak dan kewajiban. Perusahaan pengangkutan yang bertindak sebagai pengangkut harus melakukan kewajiban dengan apa yang diperjanjikan, dalam melaksanakan kewajiban harus diiringi dengan tanggung jawab, dan tanpa tanggung jawab prestasi tidak akan terjadi.

Desa Teluk Wetan merupakan salah satu sentra usaha yang ada di Kabupaten Jepara, tepatnya berada di Kecamatan Welahan. Mayoritas 
penduduk di desa ini bekerja di sektor industri pengolahan rotan. Selain sentra rotan di Desa Teluk Wetan, di Kecamatan Welahan masih terdapat sentra usaha lainnya yaitu sentra roti dan kue di Desa Bugo. Kecamatan yang memiliki luas wilayah 27,642 $\mathrm{km}^{2}$ berdasarkan sensus penduduk yang dilakukan oleh Badan Pusat Statistik Kabupaten Jepara akhir tahun 2018 mencapai 75.923 jiwa penduduk. Sedangkan penduduk Desa Teluk Wetan sendiri berjumlah 10.483 jiwa penduduk.

Di Desa Teluk Wetan industri pengolahan rotan dan bambu telah menjadi penyangga ekonomi hingga $80 \%$ dari total jumlah penduduknya. Industri pengolahan ini merupakan usaha rumahan (home industry). Awalnya mereka adalah pengrajin yang membuat mainan anak2 (kemanak), sulak, besek, penebah (pemukul kasur), dan kap lampu. Industri kerajinan rotan itu lalu semakin berkembang dan pemasarannya hingga ke seluruh wilayah Propinsi Jawa Tengah, Jakarta (daerah Rawasari, Cikini, dan Jatinegara - untuk produk keranjang parcel), Bandung dan Bali. Tidak hanya hasil produksinya saja yang kemudian merambah ke luar daerah namun juga para pengrajinnya. Bahkan pada era tahun 60-70an Pemerintah Jepang pernah mengundang tenaga kerja (pengrajin) dari Teluk Wetan untuk mengajari anak-anak Sekolah Dasar di Jepang agar dapat membuat barang-barang kerajinan dari rotan dan bambu. Hal ini karena Pemerintah Jepang ingin generasi muda Jepang dapat memanfaatkan bambu yang banyak tumbuh di Jepang dan menjadi salah satu sumber daya hayatinya.

Secara umum, hubungan kerja yang terbentuk antara majikan dan pekerja di Desa Teluk Wetan dilatarbelakangi adanya hubungan keluarga, kerabat, tetangga dan pertemanan. Hampir tidak dijumpai adanya pekerja dari luar Desa Teluk Wetan. Bilapun ada, hanya beberapa saja dan itu pun berasal dari daerah yang juga memiliki potensi lokal yang sama di industri pengolahan rotan. Misalnya dari Solo, Cirebon, Purwodadi dan Desa Sidi Gede. Yang terakhir disebutkan merupakan tetangga desa.

Dalam hubungan kerja yang terjadi di industri ini segala sesuatunya dilakukan berdasarkan rasa kekeluargaan seperti lazimnya 
usaha di sektor informal lainnya. Tidak berbeda dengan usaha lainnya, di industri pengolahan rotan ini pun sistem pengupahan disesuaikan dengan jenis pekerjaan dan beban pekerjaan itu sendiri. Industri pengolahan rotan ini menghasilkan 2 (dua) jenis hasil produksi. Pertama, hasil produksi yang berupa mebel/furniture dan yang kedua adalah hasil produksi yang berupa handycraft.

Dalam industri handycraft di Desa Teluk Wetan, pengupahan dengan sistem borongan per piece work. Ada yang dikerjakan di tempat usaha/di rumah majikan, ada pula yang dikerjakan di rumah masingmasing pekerja. Umumnya tiap pekerja perempuan mendapatkan upah Rp.20.000-Rp.25.000 per piece work, tergantung pada tingkat kesulitan produk dan ketrampilan yang dimilikinya. Namun ada pula pekerja yang hanya mendapatkan Rp.5000 per piece work. Upah yang diterima oleh tiap pekerja jumlahnya berbeda-beda menurut jumlah barang yang dikerjakannya dan menurut harga yang disepakati dengan masingmasing majikan/pemberi kerja. Tiap pekerja dapat saja menerima order dari beberapa majikan sekaligus.
Konsekuensinya adalah barang harus diserahkan tepat waktu. Kondisi ini terjadi akibat kecilnya upah yang umumnya diberikan oleh para majikan sehingga mereka terpaksa harus menerima beberapa order sekaligus. Berbeda dengan pekerja laki-laki yang bekerja dengan jam kerja yang pasti, yaitu dari jam 09.0017.00 namun mendapat upah yang jauh lebih besar bila dibandingkan pekerja perempuan. Seorang pekerja laki-laki pada industri handycraft bias mendapatkan upah Rp.50.000Rp.60.000 per hari. Mereka juga tidak bekerja dengan target. Artinya, dalam sehari produk yang dihasilkan oleh seorang pekerja perempuan dapat lebih banyak jumlahnya dari pekerja laki-laki namun upah yang didapat oleh seorang pekerja perempuan belum tentu sebanyak upah pekerja laki-laki per harinya.

Hak adalah sesuatu yang melekat dalam diri seseorang dan dapat dipaksakan pemenuhannya oleh hukum. Hak yang dimiliki oleh tiap orang terbagi dalam dua kategori menurut sumbernya, yaitu Hak Asasi dan hak yang lahir dari sebuah perjanjian. Hak Asasi terbagi lagi dalam dua kategori, yaitu Hak Asasi Manusia (hak yang dimiliki oleh 
manusia secara kodrati) dan Hak Asasi (Dasar) Warga Negara (Krisdiyatmoko, 2003). Keduanya dibedakan oleh ruang lingkup perlindungan hukumnya dalam konstitusi. Hak Asasi Manusia dalam konstitusi selalu menyangkut hak-hak dasar penduduk di suatu wilayah (warga negara dan orang asing yang tinggal di wilayah tersebut). Artinya implementasi perangkat hukum yang melindunginya tidak mengenal kewarganegaraan. Sedangkan Hak Asasi (Dasar) Warga Negara atau yang sering disebut juga dengan Hak Warga Negara/Hak Dasar merupakan hakhak yang diberikan kepada warga negara di wilayah tersebut. Hak Warga Negara tidak hanya mencakup hak sipil dan politik saja, namun juga hak ekonomi, sosial dan budaya.

Hak Dasar ini terbagi dalam dua kategori berdasarkan proses pemenuhannya. Hak sipil dan politik merupakan Hak Asasi Manusia sebagai individu sehingga dicapai dengan sendirinya atau negara memiliki kewajiban untuk menjamin pelaksanaannya. Negara dapat dituntut di muka pengadilan bila terjadi pelanggaran hak-hak tersebut terhadap warga negaranya sehingga selalu dirumuskan dalam bahasa sebagai freedom from (bebas dari). Sebaliknya hak ekonomi, sosial dan budaya dicapai oleh seorang warga negara secara bertahap dengan keterlibatan negara secara aktif melalui kebijakan-kebijakan dan upaya-upaya lain dalam pemenuhannya. Sebagai kontra prestasinya maka negara tidak dapat dituntut bila terjadi pelanggaran terhadap hak-hak tersebut sehingga selalu dirumuskan dalam bahasa dengan rights to (hak atas). Ketegorisasi ini tidak membelenggu peran negara an sich seperti yang telah didefinisikan sebelumnya karena saat ini negara juga mulai dituntut untuk berperan aktif untuk mencegah tindakan yang dapat menyebabkan seorang warga negara kehilangan pekerjaannya secara tidak adil.

Dalam kategori yang kedua, hak ekonomi merupakan hak dasar yang paling utama karena menyangkut pemenuhan kebutuhan pokok manusia. Hak ekonomi juga seringkali dijadikan standar dari sebuah demokratisasi di sebuah negara. Negara yang belum sepenuhnya menjamin hak ekonomi warga negaranya masih dianggap belum sepenuhnya demokratis atau 
bahkan diposisikan sebagai negara yang otoriter sehingga dalam kondisikondisi tertentu di dunia politik internasional hal ini sering dimanfaatkan sebagai alasan untuk melakukan pressure (tekanan) terhadap suatu negara.

$$
\text { Berdasarkan peraturan }
$$
perundang-undangan di Indonesia, tiap warga negara tanpa terkecuali tidak hanya terjamin haknya untuk mendapatkan pekerjaan dan penghasilan yang layak guna mencukupi kebutuhan hidupnya tapi juga wajib didukung oleh negara untuk mendapatkan pendidikan dan ketrampilan guna memenuhi hak ekonominya tersebut. Selain UndangUndang Dasar 1945, Pemerintah Indonesia juga telah meratifikasi International Covenant On Economic, Social, And Cultural Rights (ECOSOC) pada tahun 2005. Dalam Pasal 6 dan 7 Undang-Undang Nomor 11 Tahun 2005 tentang Pengesahan Kovenan Internasional Tentang Hak-Hak Ekonomi, Sosial dan Budaya menjamin bahwa tiap orang berhak atas pekerjaan dan berhak menikmati kondisi kerja yang adil dan menyenangkan. Dalam Pasal 6 ayat (2) undang-undang ini disebutkan bahwa negara juga wajib menyelenggarakan program pelatihan dan kejuruan, baik secara teknis maupun melalui kebijakan-kebijakan yang mendukung pemenuhan hak ekonomi disamping juga menyediakan lapangan kerja yang memadai bagi warganya. Hal ini menegaskan tiap warga negara dijamin hak ekonominya secara autentik oleh negara. Meskipun demikian, tidak serta merta peran negara menjadi satu-satunya faktor penentu dalam pemenuhan hak ekonomi seorang warganya. Negara hanya menjamin warganya untuk bebas menentukan dan mendapatkan pekerjaan yang dapat memberikan penghasilan baginya. Negara juga hanya menjamin warganya mendapatkan haknya di lingkungan kerjanya, seperti perlakuan yang manusiawi dan tidak diskriminatif.

Istilah "sektor informal" telah banyak digunakan sejak akhir tahun 1970-an. Namun, istilah ini pertama kali diperkenalkan oleh K.Hart dalam tulisannya yang berjudul Informal Income Opportunities And Urban Employment in Ghana (1971). Awalnya istilah sektor informal untuk mengacu segala hal atau kegiatan ekonomi yangberada di luar sistem formal. Pada perkembangannya 
istilah ini mengalami banyak padanan kata atau bahkan yang berkonotasi negatif. Seperti misalnya illegal; underground (Edgar, 1989) atau black economy (Lubell 1989). Semua istilah itu merujuk pada satu pola kerja yang tidak memiliki kerangka acuan baku dalam seluruh sistem operasionalnya.

Dari beberapa definisi yang ada, sesungguhnya definisi yang paling sering dirujuk oleh masyarakat mengenai sektor informal adalah yang dikemukakan oleh Hans Singer yang menyatakan bahwa usaha sektor informal ibarat jerapah. Susah dijelaskan bentuknya namun mudah dikenali (Lubell, 1991). Secara umum sektor informal dapat dilihat dari ciricirinya yang serba bertentangan dengan sektor formal. Tidak terpola secara sistematis, baik waktu, hubungan kerja, modal maupun income, belum mengenal sistem pembukuan dan perbankan secara modern, tidak terikat pada satu usaha yang lebih besar, belum tersentuh oleh hukum dan tidak membutuhkan keahlian khusus secara formal membuat usaha di sektor informal menjadi luwes. Artinya, siapa pun dapat memasuki sektor ini sebagai tenaga kerja.
Pekerja sektor informal menurut Osterkamp adalah semua orang yang bekerja sendiri, pekerja keluarga yang tidak dibayar, pekerja dan pemberi kerja yang jumlahnya tidak lebih dari 5 sampai 10 orang (Osterkamp, 2001). Demikian pula konsep pengkategorian yang dilakukan oleh Badan Pusat Statistik (BPS) Indonesia yang membedakan tenaga kerja sebagai berikut:

1. Bekerja sendiri (sektor nonformal)

2. Bekerja sebagai buruh tidak tetap (sektor non-formal)

3. Bekerja kepada keluarga (sektor non-formal)

4. Majikan/pengusaha (sektor formal)

5. Buruh/pekerja (sektor formal) (Mulyani, 2006)

Meskipun demikian, pekerja sektor informal sendiri tidak pernah terdata secara akurat karena secara umum data yang ada selalu menempatkan pekerja di sektor ini ke dalam Usaha Kecil dan Menengah sehingga data-data tentang jumlah pekerja maupun penghasilan yang didapat dari sektor ini seringkali tumpang tindih dengan data tentang 
Usaha Kecil dan Menengah. Mengacu pada definisi yang diutarakan oleh Osterkamp tentang pekerja sektor informal, maka tiap orang yang melakukan pekerjaan di luar sektor formal dapat dikatakan sebagai pekerja sektor informal.

Definisi ini hanya mengindikasikan adanya sebuah aktifitas produksi tapi tidak mengindikasikan adanya upah atau imbalan yang dapat dinilai dengan uang sebagai kontra prestasi. Padahal dalam prakteknya banyak sekali orang yang melakukan aktifitas produksi tanpa mendapatkan upah sebagai imbalannya. Mereka umumnya memiliki hubungan keluarga dengan orang yang menjadi pekerja di suatu usaha di sektor informal. Misalnya anak yang orang tuanya bekerja dengan sistem borongan, maka ia akan membantu untuk mengerjakan sebagian pekerjaan orang tuanya agar dapat diselesaikan lebih cepat sehingga dapat menerima order lagi dari majikan. Anak yang membantu orang tuanya tidak mendapat upah karena hubungan kerja yang terbentuk adalah sistem borongan antara pemberi kerja/majikan dengan pekerja. Meskipun menurut definisi
Osterkamp mereka dapat disebut juga sebagai pekerja sektor informal namun mereka tidak mendapatkan upah. Seandainya pun dibayar, upahnya sangat rendah karena dianggap sebagai pekerjaan sampingan. (Chotim, 1994)

Peraturan perundang-undangan yang ada di Indonesia saat ini belum menjangkau usaha di sektor informal, terutama dalam hal ketenagakerjaannya. Undang-Undang Nomor 13 Tahun 2003 tentang Ketenagakerjaan pun baru mengatur secara implisit dalam Pasal 64-66 tentang hal yang menyangkut sektor informal, yaitu hubungan kerja subkontrak antara perusahaan sebagai prinsipal dengan perusahaan lain sebagai subkontraktor (outsourcing). Hanya saja pasal-pasal ini kemudian mengundang reaksi dari beberapa kalangan, terutama Serikat Buruh yang menilai bahwa pasal ini memberi peluang bagi pengusaha untuk mempekerjakan tenaga kerja dengan sistem kontrak. Selain itu sebenarnya perjanjian pemborongan merupakan salah satu bentuk perjanjian umum yang tidak perlu diatur dalam undang-undang ketenagakerjaan. Perjanjian pemborongan merupakan 
kesepakatan antara dua subyek hukum, yaitu perusahaan yang berperan sebagai prinsipal dengan perusahaan yang menjadi subkontraktornya.

Bila dicermati lebih lanjut, sesungguhnya perlindungan negara secara hukum bagi pekerja sektor informal telah termuat dalam Pasal 66. Pasal ini secara tegas mengatur pembagian kerja yang boleh dilakukan oleh pekerja dari perusahaan subkontraktor, yaitu hanya melakukan pekerjaan yang sifatnya sebagai penunjang kegiatan pokok perusahaan prinsipal saja atau kegiatan lain yang tidak berhubungan langsung dengan proses produksi. Hal ini mengindikasikan adanya peluang bagi pekerja sektor informal untuk mendapatkan upah sesuai standar UMR dan jaminan sosial, sebab pasal ini juga mewajibkan pada perusahaan penyedia jasa yang menjadi subkontraktor untuk melakukan perjanjian tertulis dengan pekerjanya. Hanya saja perusahaan penyedia jasa seringkali melakukan pressure terselubung melalui kontrak per tahun sehingga pekerja yang pada dasarnya sangat membutuhkan pekerjaan tidak memiliki posisi tawar (bargaining position) terhadap jumlah upah yang ditawarkan akibat tergantung secara psikologi.

$$
\text { Pada dasarnya dalam }
$$
komunitas industri dan perdagangan yang tergolong dalam skala kecil dan menengah yang umumnya merupakan usaha sektor informal, sebagian besar pelakunya adalah perempuan. Pekerja perempuan pun diakui jauh lebih trampil dan tekun dibanding pekerja laki-laki. Hanya pada beberapa bagian produksi memang ada yang tidak mungkin dimasuki oleh pekerja perempuan. Tidak hanya dari segi kualitas produk saja namun dari segi kuantitas di beberapa sektor usaha pekerja perempuan telah membuktikan kemampuannya untuk bersaing dengan pekerja laki-laki, sehingga terlalu jelas gap gender yang dibangun untuk membedakan perlakuan terhadap pekerja di lingkungan kerja. Banyak kalangan yang telah mengupayakan adanya suatu strategi pemberdayaan bagi kaum perempuan, khususnya pekerja perempuan, namun selalu terkendala untuk menemukan satu bentuk konkret mengenai peranan perempuan dalam aktifitas ekonomi yang tak terlepas dari peranannya dalam rumah tangga. 
Secara bahasa, margin adalah tepi atau batas. Dalam Kamus Besar Bahasa Indonesia (KBBI), kata marginalisasi adalah usaha membatasi atau sebuah pembatasan. Dalam sektor informal, marginalisasi perempuan dalam hubungan produksi pun sering terjadi, bahkan dapat juga terjadi perbedaan perlakuan di antara sesama pekerja perempuan. Sementara dalam hubungan subkontrak marginalisasi perempuan terjadi dengan adanya introduksi teknologi yang membuka kesempatan pada pekerja laki-laki. Marginalisasi perempuan dalam hubungan produksi biasanya terjadi dalam beberapa bentuk, yaitu:

1. Marginality as exclusion from productive employment: marginalisasi dari pekerjaan produktif, yaitu yang menghasilkan upah dan nilai tambah,

2. Marginality as concentration on the margins of the labour market: marginalisasi ke sektor informal,

3. Marginality as feminization of segretation: penggunaan tenaga kerja perempuan untuk sektorsektor produktif tertentu,
4. Marginality as economic
inequality: ketimpangan ekonomi antara perempuan dan laki-laki dengan indikasikan dengan perbedaan upah dan perbedaan akses pada keuntungan dan fasilitas kerja. (Peter, 1986)

Seperti yang telah dijelaskan sebelumnya di atas, marginalisasi terhadap pekerja perempuan di Desa Teluk Wetan, sekalipun sangat dipengaruhi oleh nilai-nilai budaya yang masih hidup dalam masyarakatnya namun juga tidak terlepas dari potensi dasar yang dimiliki pekerja itu sendiri. Keduanya akan saling mempengaruhi dalam proses marginalisasi sebagai faktor eksternal dan internal. Dalam kasus yang terjadi di Desa Teluk Wetan kedua faktor itu memiliki korelasi positif dalam proses marginalisasi terhadap pekerja perempuan di industri handycraft rotan, sehingga tanpa disadari kondisi itu menjadi sebuah pola dalam perikehidupan masyarakat di Desa Teluk Wetan.

Dalam kasus pekerja perempuan industri perempuan industri handycraft di Desa Teluk Wetan, marginalisasi itu termasuk 
dalam bentuk marginality as economic inequality, yaitu pelebaran ketimpangan ekonomi antara perempuan dan laki-laki dengan indikasikan dengan perbedaan upah dan perbedaan akses pada keuntungan dan fasilitas kerja. Pekerja perempuan mendapatkan upah yang lebih rendah dari pekerja laki-laki akibat beban kerja yang berbeda. Namun sesungguhnya pembedaan beban kerja ini merupakan satu alasan untuk membatasi akses pekerja perempuan terhadap berbagai fasilitas dan kemungkinan akan adanya tuntutan kenaikan upah sehingga dapat membengkakan biaya operasional usaha (cost operational).

Selain itu dengan adanya peningkatan kemampuan pekerja perempuan berarti para majikan tidak lagi dapat menekan mereka karena kesetaraan kemampuan berarti juga kesetaraan upah antara pekerja lakilaki dan perempuan sehingga persaingan diantara sesama majikan menjadi semakin ketat untuk mendapatkan pekerja yang trampil.

Peran hukum dalam reposisi hak wanita di Indonesia, terutama di sektor ekonomi, seharusnya dapat dirasakan oleh semua perempuan di Indonesia mengingat perangkat hukum yang telah kita miliki selama ini. bahkan sebagai salah satu negara anggota PBB Indonesia telah meratifikasi beberapa Konvensi ILO yang dapat menghapus diskriminasi terhadap pekerja perempuan. Misalnya Konvensi ILO No.100 yang menyatakan bahwa pada prinsipnya seluruh pekerja berhak mendapatkan gaji yang sama untuk pekerjaan yang sama tanpa membedakan gender.

Konvensi itu juga memberikan kemungkinan untuk mengungkap kasus-kasus yang bertentangan dengan prinsip tersebut di atas sekaligus mencarikan solusi pemecahannya melalui berbagai program peningkatan kualitas pekerja secara keseluruhan. Umumnya ketidakadilan gender ini menimpa pekerja perempuan di sektor informal karena sektor ini tidak berada dalam sistem hukum atau berada di luar jangkauan hukum.

Dalam beberapa kasus lain, diskriminasi terhadap pekerja perempuan sektor informal tidak hanya dalam bentuk marginalisasi namun juga secara ekstrim dalam bentuk perlakuan yang semena-mena. 
Seperti misalnya pemutusan hubungan kerja kepada pekerja perempuan yang hamil atau menikah. Mereka dianggap kurang produktif dalam kedua status tersebut. Fungsi reproduksi yang merupakan fungsi kodrati dari Tuhan Yang Maha Kuasa seringkali justru membuatnya mengalami kesulitan akibat kesewenang-wenangan majikan. Atau diskriminasi lain dalam bentuk perbedaan tunjangan atau bantuan biaya saat melahirkan.

Banyak sekali ditemui kasus dimana pekerja laki-laki yang istrinya melahirkan bisa mendapatkan bantuan dari majikan/pemilik usaha, baik dalam bentuk bantuan cumacuma maupun terhitung sebagai pinjaman lunak (kas bon), namun tidak sebaliknya dengan pekerja perempuan yang melahirkan. Mereka dianggap menjadi tanggung jawab suaminya. Kalaupun ada bantuan dari majikan/pemilik usaha yang sifatnya cuma-cuma (sumbangan) jumlahnya tidak sebanyak yang didapat oleh pekerja laki-laki dan telah cukup lama bekerja di tempat itu. Artinya, untuk mendapatkan fasilitas dan kemudahan seperti yang didapatkan pekerja laki-laki pada umumnya di sektor informal, pekerja perempuan membutuhkan alasan yang cukup kuat dan memberikan jasa yang lebih besar untuk pekerjaan yang sama dibanding pekerja laki-laki.

Bicara mengenai pekerjaan yang sama dengan upah yang berbeda antara pekerja perempuan dan pekerja laki-laki sebenarnya kurang manusiawi bila melihat pada banyak faktor yang melatarbelakangi keterlibatan mereka dalam usaha di sektor informal. Secara perspektif hukum, marginalisasi dalam bentuk apapun melanggar:

1. Pasal 27 ayat (2) UUD tentang hak warga negara untuk mendapatkan pekerjaan dan penghidupan yang layak bagi kemanusiaan,

2. Pasal 28D ayat (2) UUD tentang hak setiap orang untuk bekerja serta mendapat imbalan dan perlakuan yang adil dan layak dalam hubungan kerja,

3. Undang-Undang Nomor 39 Tahun 1999 tentang Hak Asasi Manusia,

4. Ratifikasi Konvensi ILO No.100 tentang Penghapusan Diskriminasi Terhadap Pekerja Perempuan. 
Penyadaran tentang hak pekerja perempuan, baik dalam konteks ekonomi maupun dalam konteks fungsi kodratinya, sebenarnya tidak hanya tergantung pada berbagai kebijakan pemerintah saja, namun lebih pada teknis sosialisasinya. Peran pemuka agama dan tokoh masyarakat dapat dimanfaatkan sebagai salah satu sarana penyampai sekaligus monitoring terhadap emansipasi perempuan dalam berbagai aspek kehidupan. Seperti misalnya masyarakat Desa Teluk Wetan yang dalam kehidupan sehari-hari cukup religius.

Peran alim ulama (pemuka agama) di Desa Teluk Wetan ternyata sangat penting dalam kehidupan mereka. Dari informasi yang berasal dari masyarakat sekitar, pemilik usaha yang cenderung religius seringkali dijadikan panutan bagi pengembangan usaha di Desa Teluk Wetan. Kenyataan ini menunjukan bahwa sesungguhnya formula sosialisasi di Desa Teluk Wetan telah ada sejak dulu hanya belum disadari oleh masyarakatnya yang menginginkan perubahan. Formula itu adalah penyuluhan melalui ceramah-ceramah keagamaan dan berbagai kegiatan lain yang masih terhubung dengan nafas Islam (seluruh penduduk Desa Teluk Wetan adalah penganut agama Islam). Hal ini sangat memungkinkan untuk merubah cara pandang/konsep tentang peran seorang perempuan dalam masyarakat yang sebenarnya juga telah didukung oleh Islam sejak dulu.

\section{KESIMPULAN}

Berdasarkan uraian yang telah dipaparkan sebelumnya, maka dapat ditarik kesimpulan sebagai berikut: bahwa proses marginalisasi terhadap hak ekonomi pekerja perempuan di Desa Teluk Wetan, Kecamatan Welahan, Kabupaten Jepara termasuk dalam jenis marginality as economic inequality: pelebaran ketimpangan ekonomi antara perempuan dan lakilaki dengan indikasikan dengan perbedaan upah dan perbedaan akses pada keuntungan dan fasilitas kerja. Hal ini tentu saja melanggar peraturan hokum yang ada di Indonesia, yaitu :

1. Pasal 27 ayat (2) UUD tentang hak warga negara untuk mendapatkan pekerjaan dan penghidupan yang layak bagi kemanusiaan,

2. Pasal 28D ayat (2) UUD tentang hak setiap orang untuk bekerja 
serta mendapat imbalan dan perlakuan yang adil dan layak dalam hubungan kerja,

3. Undang-Undang Nomor 39 Tahun 1999 tentang Hak Asasi Manusia,

4. Ratifikasi Konvensi ILO No.100 tentang Penghapusan Diskriminasi Terhadap Pekerja Perempuan.

Adapun upaya yang dapat dilakukan untuk meminimalisir proses marginalisasi itu sendiri adalah melalui pendekatan budaya terhadap cara pandang masyarakatnya yang dikenal cukup religius. Hal ini merupakan salah satu solusi yang dapat diambil demi meningkatkan peran perempuan dalam hal ekonomi.

\section{DAFTAR PUSTAKA}

Arifin, H. 2004, Cara Memahami Kerentanan Perempuan Pengusaha Kecil, Jurnal Analisis Sosial Volume 9 No. 2, Akatiga, Bandung

Bloom, M., 1990. The Psychosocial Constructs of Social Competency. In Developing Social Competence in Adolescence. Gullota, T.P.Adams, G. R. and Montemayor (Eds), Raymond. California: Sage Publications. The International Professional Publishers.
Chotim, Erna Ernawati, 1994, Subkontrak dan Implikasinya Terhadap Pekerja Perempuan: Kasus Industri Kecil Batik Pekalongan, Akatiga, Bandung.

De Soto, Hernando 1989, The Other Path: The Invisible Revolution in the Third World, New York: Harper \& Row Publishers

Dicken, Peter, 1986, Global Shift: Industrial Change in A Turbulent World, London

Edgar L. Feige (ed), 1989, The Underground Economies: Tax Evasion and Information Distortion, Cambridge: Cambridge University Press

Hart, K., 1971, "Informal Income Opportunities and Urban Employment in Ghana", in: R.Jolly et al. (eds.): Third World Employment: Problems and Strategy, Harmondsworth: Penguin

ILO Kenya Report, 1972

J. Goode, William, Sosiologi Keluarga, Alih Bahasa Lailahanaoum Hasyim, Edisi Pertama, Jakarta, Bumi Aksara

Jong, De S., 1976. Salah Satu Sikap Hidup Orang Jawa, Yogyakarta: Yayasan Kanisius.

Kamus Besar Bahasa Indonesia

Koentjaraningrat. 1999. Kebudayaan Jawa. Jakarta: CV Jambatan

Krisdyatmoko, 2003, mengutip Maurice Cranston dalam makalahnya "Konsep Dasar, Sejarah Dan Perkembangan Hak-Hak Asasi Manusia Dan Hak-Hak Warga Negara", IREPemberdayaan Masyarakat Adat.

Lubell, Harold, 1991, The Informal Sector in 1980s and 1990s, Paris: Organization for 
Economic Cooperation and Development

Mulyani, Lilis dan Tri Widya Kurniasari, 2006, Perlindungan Hukum dan Sosial Pekerja Sektor Informal: Studi Kasus Pekerja Industri Informal Sandang dan Kerajinan di Kota Bandung, Kota Denpasar dan Kabupaten Badung, Jakarta, PMB dan LIPI-Press

OECD, 2002, Handbook for measurement of Underground, informal and illegal activities (non-observed economy), diambil dari <http://www.oecd.org/datao ecd/9/20/ 1963116.pdf>

Osterkamp, 2001, Informal Sector, Article for Course on National Account, 11-12 June 2001

Saleh, Irsan Azhary, 1986, Industri Kecil Sebuah Tinjauan Dan Perbandingan, Jakarta

Smith, M. Estellie, et.al., (eds), 1990, Perspectives on the Informal Economy: Monograph in Economic Anthropology No. 8

Silverman, LK, (1993). Counseling the Gifted and Talented, Denver, Colorado; Love Publishing.

Widyorini, Endang, Perempuan Berbakat Dalam Budaya Jawa, www.unika.ac.id/fakultas/psi kologi/artikel/ew-1.pdf - 